\title{
Soil Acidity Management and an Economics Response of Lime and Sulfur on Sesame in an Alley Cropping System
}

\author{
Sandeep Kumar ${ }^{1,2}$, Ram Swaroop Meena ${ }^{2,4}$, Achyutanand Pandey ${ }^{2}$ and Seema ${ }^{3}$ \\ ${ }^{1}$ Department of Agronomy, CCS Haryana Agricultural University, \\ Hisar, Haryana, India - 125004 \\ ${ }^{2}$ Department of Agronomy, ${ }^{3}$ Soil Science and Agril. Chemistry, Banaras Hindu University, \\ Varanasi (UP)-221 005, India-2210 05 \\ ${ }^{4}$ School of Environment and Natural Resources, The Ohio State University, \\ Columbus, OH, USA- 43210 \\ *Corresponding author
}

\begin{tabular}{|c|c|}
\hline & A B S T R A C T \\
\hline Keywords & \multirow{7}{*}{ 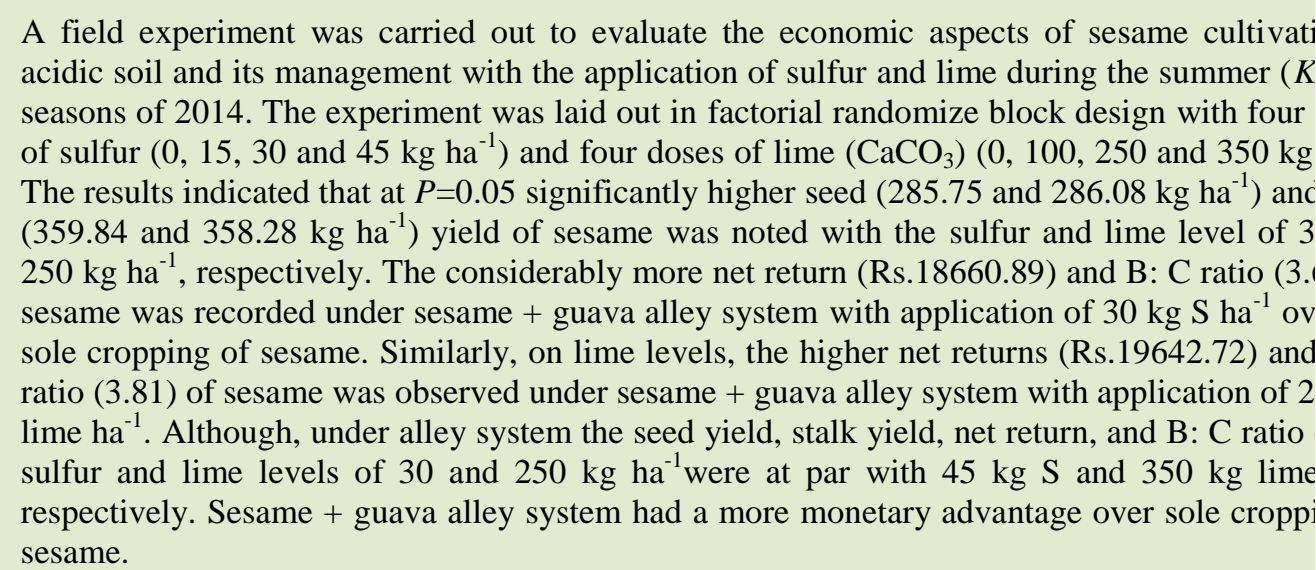 } \\
\hline $\mathrm{B}: \mathrm{C}$ ratio, & \\
\hline Economics, & \\
\hline $\begin{array}{l}\text { Lime, Net return, } \\
\text { Sesame, }\end{array}$ & \\
\hline Sulfur & \\
\hline Article Info & \\
\hline $\begin{array}{l}\text { Accepted: } \\
\text { 20 January } 2017 \\
\text { Available Online: } \\
10 \text { March } 2017\end{array}$ & \\
\hline
\end{tabular}

\section{Introduction}

Sesame (Sesamum indicum) is one of the important and oldest indigenous oilseed crops belonging to genus Sesamum with the longest history of its cultivation in India. Its seed contains the highest oil compared to any other oilseed to the extent of $50 \%$ and above (Hwang, 2005). India is still the world leader in the maximum $(25.8 \%)$ production from the largest $(29.8 \%)$ area in the world. Sesame seed is qualitative, nutritious and highly rich in protein and essential amino acid (e.g. methionine) essential for human body. Sesame seed is also an excellent source of vitamins (e.g. E, A, B,$B_{2}$, and niacin) and mineral nutrients like calcium $(1450 \mathrm{mg} / 100 \mathrm{~g})$ and phosphorous $(570 \mathrm{mg} / 100 \mathrm{~g}$ ) (Shah et al., 2013). The sesame oil is mostly used for edible purpose due to its superior quality because it contains less amount of eurocic acid and high amount of linoleic acid which is beneficial for human health. 
Sulfur plays a key role in production of oilseed crops. Sesame is sulfur loving crop in the presence of that the quantity and quality of sesame produce can be enhanced. Approximately $12 \mathrm{~kg} \mathrm{~S}$ is required to produce one ton of oil seed (Ghosh et al., 2000). Sulfur is one of the dominant factors for yield and oil content of sesame, research in this line is important for increasing yield of this crop as sulfur deficiency alone reduces crop yield by 10-20\% (Bhuiyan and Shah, 1990). Also, the $\mathrm{pH}$ of the soil affects the bioavailability of plant nutrients and so, indirectly, crop growth and development. Soil acidity is ameliorated by applying lime or other acid-neutralizing materials. Liming to recommended soil $\mathrm{pH}$ values increases productivity, benefits soil structure, improves degraded soils and, when used with other appropriate management practices, can benefit crop biodiversity (Goulding, 2016).

Sesame is widely accepted crop for dryland agriculture. Alley cropping system is increasingly viewed as an effective means towards increasing crop and fruit tree productivity under the acidic soil. Therefore, the location specific according to agroecological zones selection of an appropriate combination of fruit and arable crop in alley cropping in crucial. A major objective of alley cropping is to attain stability in crop yield while maintaining or enhancing the soil productivity and sustainability. Alley cropping of Psidium guajava (Guava) with arable crops like sesame is more remunerative than the sole crop of sesame in acidic soils (Kumar et al., 2013). In such problematic soils, the net return from a unit land area under alley cropping is considerably higher than those from the annual sole crop (Malavia and Patel, 1989). The results on such aspects have revealed better return from unit land compared to a traditional practicing system. Therefore, need to focus on alley copping system because of low input required $\&$ high price of produce.
The present experiment was laid out with the hypothesis that sulfur and lime application can improve the yield and economics of sesame under alley cropping with guava planted on acidic soils of eastern Uttar Pradesh, India.

\section{Materials and Methods}

\section{Site Description and Experimental Details}

The research was conducted in summer season of 2014 in sandy loam soils at Agronomy Farm of RGSC, Banaras Hindu University, situated at Barkachha, Mirzapur, India having latitude, longitude and altitude above mean sea level of $25^{\circ} 05^{\prime}, 82^{\circ} 59^{\prime}$ and 89 meters, respectively the Northern Gangetic alluvial plains. The experiment was laid out in factorial randomized block design in three replicate times with 16 treatment combinations, comprising four levels of sulfur $\left(0,15,30\right.$ and $\left.45 \mathrm{~kg} \mathrm{ha}^{-1}\right)$ and four levels of lime $\left(0,100,250\right.$ and $\left.350 \mathrm{~kg} \mathrm{ha}^{-1}\right)$ with net plot size of $4.4 \mathrm{~m} \mathrm{x} 3.4 \mathrm{~m}$.

\section{Cultural Practices}

The experiment was conducted under rainfed area; hence the seedbed was prepared on the already stored moisture regime by rainfall. Elemental sulfur $\left(\mathrm{S}^{0}-\mathrm{S}\right)$ and lime $\left(\mathrm{CaCO}_{3}\right)$ was applied 15 days before the sowing of crop according to the treatment requirements and thoroughly incorporated into the soil with the help of spade. The sowing was performed on August 06, 2014 using country plough by keeping row to row distance of $30 \mathrm{~cm}$ with 2.5 $\mathrm{cm}$ depth and seed rate of $4 \mathrm{~kg} \mathrm{ha}^{-1}$. The sowing was done between the alleys of 8 years old guava spaced at $7 \mathrm{~m} \times 7 \mathrm{~m}$ distance which was planted in August 2006. After attaining constant emergence count, thinning was done at 15 days after sowing to maintain the plant to plant distance of $10 \mathrm{~cm}$. Fertilizers at the rate of $30 \mathrm{~kg} \mathrm{~N}, 60 \mathrm{~kg} \mathrm{P}$ and $30 \mathrm{~kg} \mathrm{~K}$ were applied as basal dose through Urea, Diammonium phosphate and Muriate of potash. 
Weeds were removed manually at 20 days after sowing.

At maturity, total plants present in each net plot were harvested after removing the border rows, tied into bundles, numbered and left out in the field to dry for 4-5 days. After proper cleaning and winnowing the seed weight of each plot was recorded separately. The cost of cultivation including weeding and harvesting of the fruit tree were considered common in all treatments while the cost of various mulching practices varied due to their requirement as per treatment. Gross income was worked out by multiplying grain and stalk yields of the crop and yield of fruit trees with their prevailing market prices. Calculations were made as per normal rates prevalent at the Research Farm, RGSC (BHU). The cost of lime and sulfur was taken as per prevailing market prices. Net return (Rs. ha ${ }^{-1}$ ) and benefit: cost ratio was calculated with the help of the following formulas:

Net return $\left(\right.$ Rs. ha $\left.{ }^{-1}\right) \quad=$ Gross return (Rs. ha $\left.{ }^{1}\right)$ - Cost of cultivation (Rs. ha ${ }^{-1}$ )

B: C ratio Net return ( $(/ / h a)$

Cost of cultivation ( $₹ / h a$ )

Statistical analysis: All the data recorded were statistically analyzed by standard procedures of factorial randomized block design (Gomez and Gomez, 1984). Analysis of variance (ANOVA) was used to short out total variance and estimate variance component and to test the predominant hypothesis. Once F ratio was significant, a multiple mean comparison was performed using Fisher's Least Significance Difference Test at 0.05 probability level (Fischer, 1954).

\section{Results and Discussion}

The application of sulfur and lime levels significantly influenced the seed and stalk yield of sesame (Fig 1). Among the different levels of sulfur, $30 \mathrm{~kg} \mathrm{~S}^{-1}$ recorded significantly higher seed $\left(282.75 \mathrm{~kg} \mathrm{ha}^{-1}\right)$ and stalk $\left(359.84 \mathrm{~kg} \mathrm{ha}^{-1}\right)$ yield of sesame, which was closely followed by $45 \mathrm{~kg} \mathrm{~S}^{-1}$. Even though, the difference between 30 and $45 \mathrm{~kg} \mathrm{~S}$ $\mathrm{ha}^{-1}$ for seed and stalk yield was at par. The increased seed and stalk yield up to $30 \mathrm{~kg} \mathrm{~S}$ $\mathrm{ha}^{-1}$ were 42.62 and $29.09 \%$ over control. The sulfur application at the rate $30 \mathrm{~kg} \mathrm{ha}^{-1}$ showed the highest gross return (Rs.47136.02), net return (Rs.18660.89) and B: C ratio (3.65) in sesame + guava over the sole crop of sesame (Fig 2 and Tale 1). However, the application of $45 \mathrm{~kg} \mathrm{~S} \mathrm{ha}^{-1}$ reported statistically comparable gross return (Rs.46740.21), net return (Rs.19588.41) and B: C ratio (4.26) with $30 \mathrm{~kg} \mathrm{~S} \mathrm{ha}^{-1}$ in sesame + guava alley cropping. The increased net return and $\mathrm{B}$ : $\mathrm{C}$ ratio of sesame + guava up to $30 \mathrm{~kg} \mathrm{Sha}^{-1}$ was 53.87 and $261.38 \%$ over control, whereas, this increased net return and B: $\mathrm{C}$ ratio of sole sesame up to $30 \mathrm{~kg} \mathrm{~S}^{-1}$ was 227.11 and $202.97 \%$ over control. These results are in agreement with the findings of Nehara et al. (2006); Singh and Mann (2007); Baviskar et al. (2010); Meena and Meena (2013); Meena et al. (2013).

Amongst the lime levels, application of $250 \mathrm{~kg}$ lime $\mathrm{ha}^{-1}$ showed significantly higher seed yield, stalk yield and monetary advantage over rest of lime treatments (Fig 1). The data revealed that the considerably higher seed $\left(286.08 \mathrm{~kg} \mathrm{ha}^{-1}\right)$ and stalk (358.28 $\left.\mathrm{kg} \mathrm{ha}^{-1}\right)$ yield was obtained from the application of 250 $\mathrm{kg}$ lime $\mathrm{ha}^{-1}$. The increased seed and stalk yield up to $250 \mathrm{~kg}$ lime $\mathrm{ha}^{-1}$ were 55.62 and $26.72 \%$ over control. Similarly, more gross return (Rs.42797.85), net return (Rs.19642.72) and $\mathrm{B}$ : C ratio (3.81) was in $250 \mathrm{~kg}^{\mathrm{k}}$ lime $\mathrm{ha}^{-1}$, but these were at par with $350 \mathrm{~kg}$ lime ha ${ }^{-1}$ under sesame + guava alley cropping (Fig 2 and Tale 1). 
Int.J.Curr.Microbiol.App.Sci (2017) 6(3): 2566-2573

Table.1 Effect of sulfur and lime levels on economics of sesame and sesame + guava

\begin{tabular}{|c|c|c|c|c|c|c|}
\hline \multirow[t]{2}{*}{ Treatment } & \multicolumn{3}{|c|}{ Sesame } & \multicolumn{3}{|c|}{ Sesame + guava } \\
\hline & $\begin{array}{c}\text { Cost of } \\
\text { cultivation } \\
\text { (Rs./ha) }\end{array}$ & $\begin{array}{l}\text { Gross return } \\
\text { (Rs./ha) }\end{array}$ & B:C ratio & $\begin{array}{c}\text { Cost of } \\
\text { cultivation } \\
\text { (Rs./ha) }\end{array}$ & $\begin{array}{l}\text { Gross return } \\
\quad \text { (Rs./ha) }\end{array}$ & B:C ratio \\
\hline Control & 18121.53 & 9710.95 & 1.01 & 18121.53 & 36082.75 & 1.01 \\
\hline 15 & 23881.67 & 11914.38 & 1.71 & 23881.67 & 38379.52 & 1.60 \\
\hline 30 & 32641.53 & 14327.55 & 3.06 & 32641.53 & 47136.02 & 3.65 \\
\hline $\mathrm{CD}(\mathrm{P}=0.05)$ & & 5107.21 & 1.69 & & 4577.91 & 0.86 \\
\hline \multicolumn{7}{|c|}{ Lime levels (kg/ha) } \\
\hline Control & 22121.27 & 8396.17 & 1.09 & 22121.27 & 36517.97 & 1.03 \\
\hline 100 & 26701.67 & 10790.59 & 1.82 & 26701.67 & 42242.39 & 1.87 \\
\hline 250 & 27988.40 & 14476.05 & 3.25 & 27988.40 & 42797.85 & 3.81 \\
\hline 350 & 34401.73 & 17295.16 & 4.91 & 34401.73 & 46780.29 & 3.93 \\
\hline
\end{tabular}


Fig.1

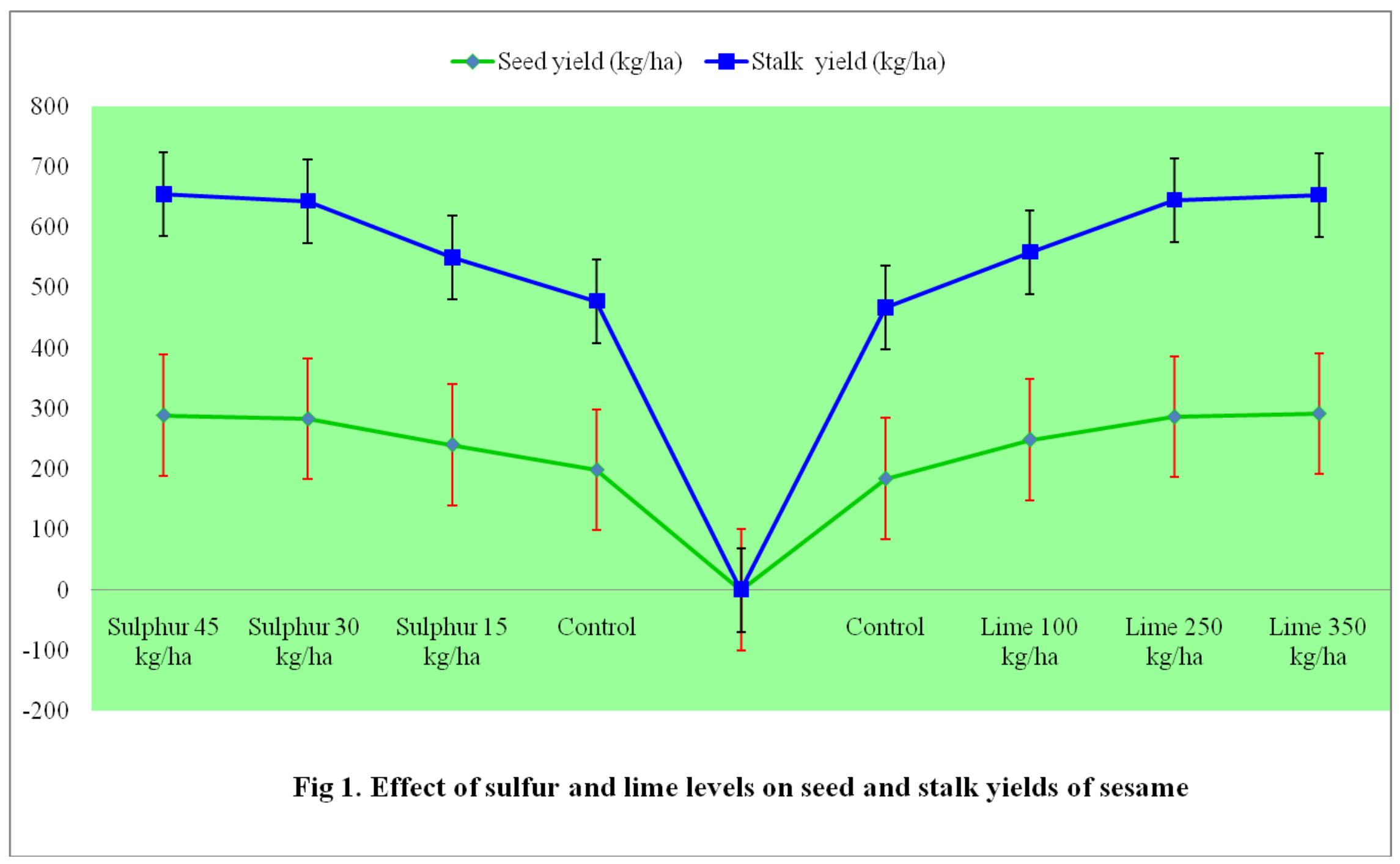


Fig.2

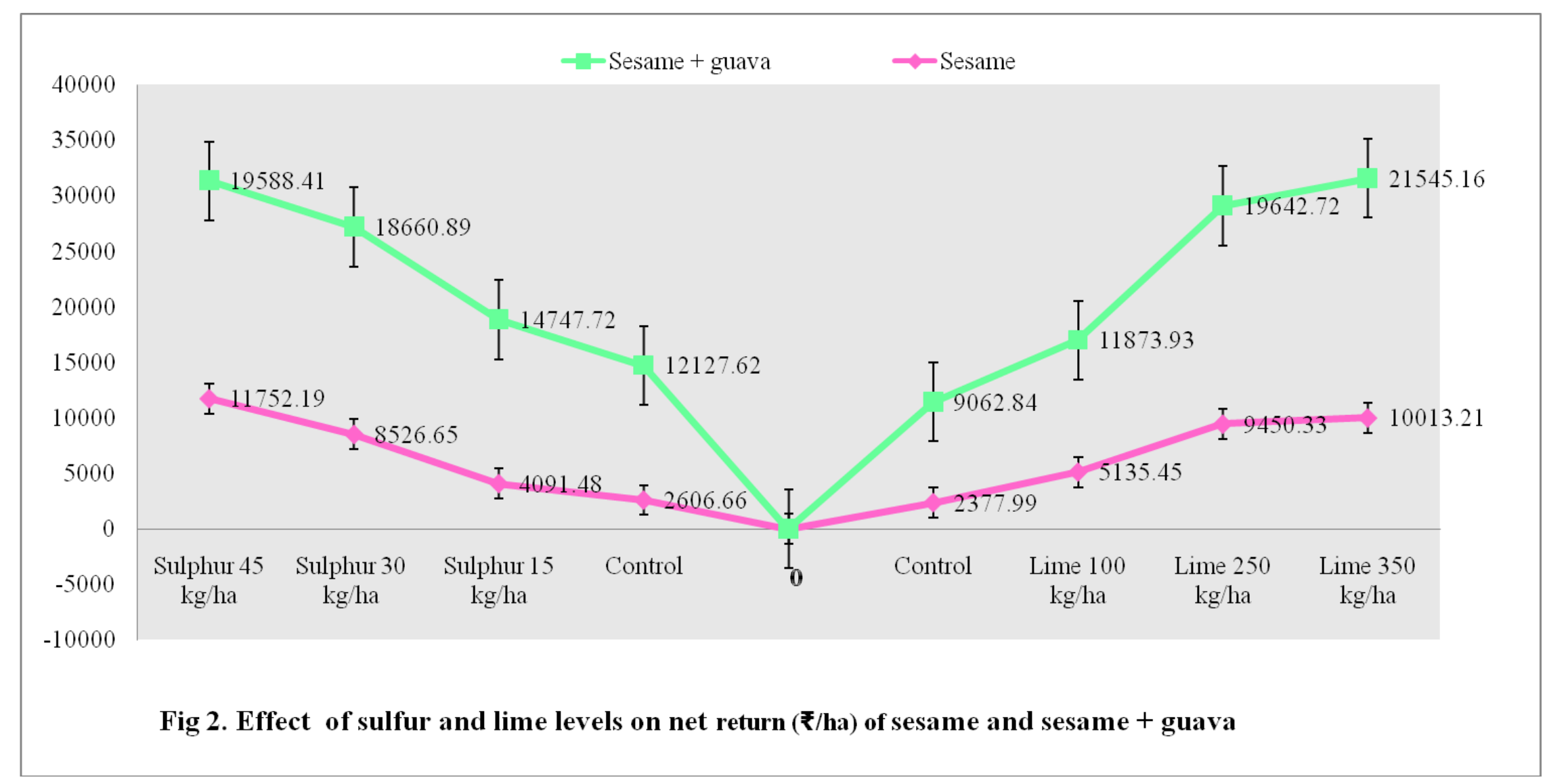


The increased net return and $\mathrm{B}$ : $\mathrm{C}$ ratio of sesame + guava up to $250 \mathrm{~kg}$ lime ha-1 was 116.63 and $269.9 \%$ over control, whereas, this increased net return and $\mathrm{B}$ : $\mathrm{C}$ ratio of sole sesame up to $250 \mathrm{~kg}$ lime ha- 1 was 297.4 and $198.16 \%$ over control.

This might be due to higher seed, and stalk yield was produced under the treatment of 250 $\mathrm{kg}$ lime $\mathrm{ha}^{-1}$. The monetary advantage in the alley cropping system of sesame + guava was higher than the growing of sesame as a sole crop. The results were close conformity with the findings of Lukina and Epplin (2003); Meena and Varma (2016); Varma et al. (2016).

In conclusion, $S$ and lime application enhanced the productivity and economic returns of sesame under sesame + guava alley system in acidic soils of eastern Uttar Pradesh and the sulfur lime level of 30 and $250 \mathrm{~kg}$ ha 1 , respectively performed better than other treatments. Therefore to attain maximum sesame productivity along with higher net returns and B: C ratio under sesame + guava alley system in acidic soils, sulfur and lime should be apply @ 30 and $250 \mathrm{~kg} \mathrm{ha}^{-1}$, respectively.

\section{References}

Baviskar, V.S., P.G. Shete and R.A. Daspute. 2010. Influence of organic fertilizers and sulfur levels on yield, quality, and economics of clusterbean (Cyamopsis tetragonoloba L. Taub.). International Journal of Agricultural Sciences 6(2): 478-480.

Bhuiyan, N.I. and A.L. Shah 1990. Evaluation of sulfur for wet land rice. Extended Symp. 15 Ann. Bangladesh Sci. Conf. BAAS. Dhaka.p. 4.

Fisher, R.A. 1954. Statistical methods for research workers.12th ed., Hafner, New York, pp.1-356.
Ghosh, P.K.., K.M. Hati, K.G. Mandal, A.K. Misra, R.S. Chaudhary and K.K. Bandyopadhyay. 2000. Sulfur nutrition in oilseeds and oilseed based cropping systems. Fertiliser News 45(8): 27- 40.

Gomez, K.A. and A.A. Gomaz. 1984. Statistical procedures for agricultural research. John Wiley and Sons, Singapore.

Goulding, K.W.T. 2016. Soil acidification and the importance of liming agricultural soils with particular reference to the United Kingdom. Soil Use and Management 32: 390-399. Doi: 10.1111/sum.12270.

Kumar, S., R.S. Meena, P. Kumar, R.K. Dadhich and A. Singh. 2013. Effect of different spacing and fertilizer levels on yield parameters of mungbean under guava based agri-horti system. Journal of Progressive Agriculture 4(2): 14-16.

Lukina, V.V. and F.M. Epplin. 2003. Optimal frequency and quantity of agricultural lime applications. Agricultural Systems 76: 949-967.

Malavia, D.D. and J.C. Patel. 1989. Agroforestry prospects in arid and semi-arid regions of Gujarat State. National symposium on agro-forestry system in India, CRIDA, Hyderabad (Jan 11-13).

Meena, K.K. and R.S. Meena. 2013. Effect of sulfur and iron fertilization on growth parameters, yield attributes, yields and nutrient uptake of mungbean (Vigna radiataL.) in arid western Rajasthan. Environment and Ecology 31(1): 227131.

Meena, K.K., R.S. Meena and M.S. Kumawat. 2013. Effect of sulfur and iron fertilization on yield attribute, yield, nutrient uptake of mungbean (Vigna radiataL.). Indian Journal of Agricultural Science. 83(4): 108- 112.

Meena, R.S. and D. Varma. 2016. Mungbean yield and nutrient uptake performance in response of NPK and lime levels under 
acid soil in Vindhyan region, India. Journal of Applied and Natural Science 8(2): 860-863.

Nehara, K.C., P.D. Kumavat and B.P. Singh. 2006. Response of fenugreek to phosphorus, sulfur and plant growth regulator under semi-arid eastern plains zone of Rajasthan. Indian Journal of Agronomy 51(1): 73-76.

Ogasawara, T., K. Chibaand, M. Tada. in (Y. P. S. Bajaj ed). 1998. Medicinal and Aromatic Plants, volume 10. Springer. ISBN 3-540-62727-8.

Shah, M.A., A. Manaf, M. Hussain, F. Farooq and M. Zafar-ul-Hye. 2013. Sulfur fertilization improves the sesame productivity and economic returns under rainfed conditions. International Journal of Agriculture \& Biology 15(6): 13011306.

Singh, Y.P. and J.S. Mann 2007. Interaction effect of sulfur and zinc in groundnut and their availability in Tonk district of Rajasthan. Indian Journal of Agronomy 52(1): 70-73.

Varma, D., R.S. Meena, S. Kumar and E. Kumari 2016. Response of mungbean to NPK and lime under the conditions of Vindhyan region of Uttar Pradesh. Legume Research, In Press.

Hwang, L.S. 2005. Sesame oil. Bailey's Industrial Oil and Fat Products, Sixth Edition, Six Volume Set. Edited by Fereidoon Shahidi. John Wiley \& Sons, Inc.

\section{How to cite this article:}

Sandeep Kumar, Ram Swaroop Meena, Achyutanand Pandey and Seema. 2017. Soil Acidity Management and an Economics Response of Lime and Sulfur on Sesame in an Alley Cropping System. Int.J.Curr.Microbiol.App.Sci. 6(3): 2566-2573. doi: https://doi.org/10.20546/ijcmas.2017.603.291 